\title{
Uitspraken van de Governancecommissie Gezondheidszorg 2016-2019: de raad van toezicht in de schijnwerpers
}

\author{
Mr. dr. A.G.H. Klaassen*
}

\section{Inleiding}

Bij de Governancecommissie Gezondheidszorg (Governancecommissie) kunnen belanghebbenden die menen dat zij op enigerlei wijze nadeel hebben ondervonden van de wijze van naleving van de Governancecode Zorg (GCZ) door een zorgorganisatie hierover een toetsingsverzoek indienen. ${ }^{1}$ Deze GCZ geldt sinds 2017. Daarvoor gold de Zorgbrede Governancecode uit 2010 (ZGC) en daarvoor die uit 2005 en toetste de Governancecommissie aan deze governancecodes. ${ }^{2}$

In de periode 2016-2019 heeft de Governancecommissie elf uitspraken ${ }^{3}$ gepubliceerd. ${ }^{4}$ Opvallend is dat het bij deze uitspraken vooral draait om (het functioneren van) de raad van toezicht. ${ }^{5}$ De zorgorganisaties, waartegen de toetsingsverzoeken zijn ingediend, zijn stichtingen en één bv. Doel van deze bijdrage is een analyse te geven van deze elf uitspraken van de Governancecommissie en, voor zover relevant, deze uitspraken te vergelijken met uitspraken in de periode 2011-2015. ${ }^{6}$

* Ageeth Klaassen is universitair docent ondernemings- en gezondheidsrecht. Zij doceert het vak Governance in de zorg in de master Recht van de gezondheidszorg aan de Erasmus Universiteit Rotterdam; zij is lid van een raad van commissarissen van een stichting in de eerstelijnsgezondheidszorg.

1 In geval van een verwijzing naar een uitspraak gebruik ik de afkorting GG. De uitspraken zijn geanonimiseerd (art. 17 lid 3 Reglement). In deze bijdrage gebruik ik de namen zoals die in de literatuur worden gebruikt. Zie voor kritiek op het anonimiseren A.F.H. ten Brummelhuis in zijn noot bij GJ 2016/63.

2 Ik gebruik de afkortingen GCZ en ZGC. Indien het niet nodig is een onderscheid te maken tussen beide codes, gebruik ik de term 'Code' of 'governancecode'.

3 Volgens Houwen worden de uitspraken van de Governancecommissie in brede kring wel als gezaghebbend beschouwd, L.G.H.J. Houwen, 'Normen en (morele) waarden van de Governancecode Zorg', Ondernemingsrecht 2020/3, p. 19 en 21.

4 Zie http://scheidsgerechtgezondheidszorg.nl/governance/uitspraak. Sommige uitspraken zijn ook gepubliceerd in Gezondheidszorg Jurisprudentie $(G J)$, indien dat het geval is, zal ook de GJ-vindplaats genoemd worden. Opmerkelijk is dat in twee uitspraken (GG 20 december 2017 (17/01) en (17/04)) de verweerders (bijna) hetzelfde waren. Bij de ene uitspraak was een oud-bestuurder de verzoekende partij, bij de andere uitspraak was de verzoekende partij twee brancheverenigingen. Tussen beide uitspraken zit dan ook de nodige overlap. Van beide uitspraken is een aangepaste versie op de website van de Governancecommissie geplaatst vanwege kennelijke fouten in de eerdere versie (10 januari 2018). De uitspraak van de Governancecommissie van 3 januari 2020 blijft buiten beschouwing.

5 Of de raad van commissarissen, indien het een bv betreft.

6 Zie voor een analyse van de uitspraken in de periode 2011-2015, A.G.H. Klaassen, 'Uitspraken van de Governancecommissie Gezondheidszorg: de dans rond de stoel van de bestuurder’, TvGR 2016, p. 174 e.v. 
De opzet van het artikel is als volgt. Paragraaf 2 gaat in op de rol van de Governancecommissie. Paragraaf 3 behandelt de ontvankelijkheidseisen. In paragraaf 4 komen de uitspraken aan de orde. In paragraaf 5 volgt de conclusie.

\section{Governancecommissie Gezondheidszorg ${ }^{7}$}

Een toetsingsverzoek wordt in beginsel behandeld door een meervoudige Kamer van vijf leden van de Governancecommissie, waarvan de samenstelling wordt bepaald door de voorzitter. ${ }^{8}$ Van dit aantal kan worden afgeweken indien partijen daarmee akkoord zijn. ${ }^{9}$ De Governancecommissie of (een van) de partijen (of na het wisselen van de schriftelijke stukken) kan (kunnen) een mondelinge behandeling van het verzoek wensen. ${ }^{10}$ In twee gevallen heeft er geen mondelinge behandeling plaatsgevonden. ${ }^{11}$ De partijen dragen ieder hun eigen kosten in verband met de behandeling van het toetsingsverzoek door de Governancecommissie. ${ }^{12}$

\section{Taak en bevoegdheid}

De Governancecommissie heeft tot taak de behandeling en beoordeling van verzoeken van belanghebbenden tot toetsing van de naleving van een of meer principes van de GCZ door een zorgorganisatie in een concreet geval, zo staat in het Reglement. ${ }^{13}$

Niet alle soorten klachten kunnen aan de Governancecommissie worden voorgelegd. ${ }^{14}$ Kwesties die buiten het toetsingskader van de governancecode vallen, kunnen niet aan de Governancecommissie worden voorgelegd. ${ }^{15}$ Het is in de ogen van de Governancecommissie niet haar taak te oordelen over het niveau van de zorgverlening in individuele

7 Zie voor de samenstelling art. 4 Reglement Governancecommissie Gezondheidszorg (hierna: Reglement). Sinds 10 mei 2018 kent de Governancecommissie een nieuw reglement.

8 Art. 10 lid 1 Reglement. Indien de voorzitter van oordeel is dat een toetsingsverzoek spoedeisend is of zich anderszins leent voor behandeling door een enkelvoudige Kamer kan de voorzitter, al dan niet op gemotiveerd verzoek van partijen, bepalen dat het toetsingsverzoek door de enkelvoudige Kamer van de Governancecommissie wordt behandeld. De enkelvoudige Kamer wordt gevormd door de voorzitter van de Governancecommissie (art. 10 lid 3 Reglement).

9 De Governancecommissie bestond bij de volgende uitspraken uit vier leden: GG 3 januari 2017 (vanwege onvoorziene omstandigheden), GG 19 februari 2018, GJ 2018/82 (vanwege ziekte) en GG 26 februari 2019 (ActiZ/Buurtzorg), GJ 2019/89, m.nt. K.D. Meersma \& B. Verkerk (vanwege verhindering). Zie over uitstel van de behandeling van een toetsingsverzoek vanwege onvoorziene omstandigheden GG 29 oktober 2018.

10 Art. 14 lid 1 Reglement.

11 GG 29 november 2017 (RvT GGZ), overweging 1.3 en GG 30 september 2019, overweging 1.4.

12 Art. 16 lid 2 Reglement. Zie hierover GG 29 oktober 2018, overweging 4.8. De kosten van de behandeling van het toetsingsverzoek door de Governancecommissie, waaronder de honoraria en vergoeding van reisen verblijfkosten en overige kosten van de leden en (plaatsvervangend) secretaris alsmede de reis-, verblijfen verletkosten van de getuigen en deskundigen die door de Governancecommissie zijn opgeroepen, worden gedragen door de deelnemende brancheorganisaties, aldus art. 16 lid 1 Reglement.

13 Art. 6 lid 1 Reglement.

14 In de ogen van de Governancecommissie biedt het Reglement haar ook niet de mogelijkheid een vraag ambtshalve te toetsen. Zie hierover GG 29 oktober 2018, overweging 4.7. Verzoekers waren niet-ontvankelijk.

15 GG 16 april 2018, overweging 4.3. Zie ook GG 16 april 2018, overweging 4.15-4.17. De Governancecommissie gaat ook niet op kwesties in die geen onderdeel zijn van het debat tussen partijen. Zie GG 20 december 2017 (17/04), GJ 2018/59 (NVZ-ActiZ/Spijkenisse Medisch Centrum), overweging 4.1-4.3. 
gevallen, over mogelijke incidenten, de hoofdlijnen van het financiële beleid van een zorgorganisatie en de daarin gemaakte keuzen en afweging van bestuurlijke en strategische aard. ${ }^{16}$ De Governancecommissie verwijst hiervoor naar de raad van toezicht (RvT), de ondernemingsraad en de cliëntenraad, het ministerie van Volksgezondheid, Welzijn en Sport (VWS) en de Inspectie Gezondheidszorg en Jeugd (IGJ). ${ }^{17}$ Hiermee houdt de Governancecommissie zich terecht aan haar eigen reglement. Het gaat in de genoemde gevallen om een bestuurlijke verantwoordelijkheid, waarop door de RvT in eerste instantie toezicht wordt gehouden. Daarnaast houden de ondernemingsraad en de cliëntenraad vanuit de medezeggenschapsrol ${ }^{18}$ hierop toezicht en de IGJ als externe toezichthouder. ${ }^{19}$

De Governancecommissie acht zich niet bevoegd te oordelen over de (civielrechtelijke) rechtsgeldigheid van de benoeming van de leden van de RvT, de (civielrechtelijke) rechtspositie van een bestuurder of - meer in het algemeen - over de civielrechtelijke gevolgen van schending van de Code. ${ }^{20}$ Dit kan wel een rol spelen bij de vorming van het oordeel van de Governancecommissie. ${ }^{21}$

Verhouding tot Governance innovatie- en adviescommissie

De Governance innovatie- en adviescommissie (IAC), die sinds 8 juni 2017 is ingesteld, is beschikbaar voor advies over governancevraagstukken die verder reiken dan het niveau van individuele casuiistiek en vragen om een overstijgende visie. De IAC zal zich niet richten op geschilbeslechting in een concreet geval, daarvoor is de Governancecommissie, maar op verzoek van de brancheorganisaties zal de IAC wel kunnen adviseren over governancevraagstukken die zich in de praktijk voordoen. ${ }^{22}$ In haar rapport 'Good Governance: een gezamenlijke opgave - Twee jaar ervaring met de nieuwe Governancecode Zorg' kwam de IAC tot de conclusie dat er meer handvatten zijn gewenst over hoe de GCZ toe te passen. ${ }^{23}$

16 GG 16 april 2018, overweging 4.6. T.A.M. van den Ende, 'Kroniek rechtspraak Scheidsgerecht Gezondheidszorg en aanpalende geschillen', TvGR 2018, p. 314 vindt dit terecht. Zij verwijst hierbij overigens naar een andere uitspraak.

17 GG 16 april 2018, overweging 4.6.

18 Zie de WOR en de Wmcz en straks de Wmcz 2018.

19 Op grond van de Wkkgz en de WTZi. Zie ook par. 4.6.1.

20 GG 3 januari 2017, overweging 4.1 en GG 20 december 2017 (17/01) (CuraMare), overweging 4.2. Zie ook GG 19 februari 2018, GJ 2018/82, overweging 4.4. Vgl. GG 5 december 2013, GJ 2014/62 (Humanitas), overweging 3.15 en GG 24 november 2015, GJ 2016/63, m.nt. A.F.H. ten Brummelhuis (GGZ Nederland/GGZ Noord-Holland-Noord), overweging 4.3.

21 GG 20 december 2017 (17/01) (CuraMare), overweging 4.2.

22 Zie www.governancecodezorg.nl/over-de-code/innovatie-en-implementatie/. De vraag is of de gestelde vragen in GG 29 november 2017 (RvT GGZ) en GG 30 september 2019 zich meer lenen voor de Governancecommissie of de IAC. Er was in deze gevallen geen sprake van een geschil, maar de vragen waren vanuit zorgvuldigheid opgeworpen. Het lijkt mij dat als de vragen algemener waren gesteld, deze vragen ook beantwoord zouden kunnen worden door de IAC. Dit kan dan niet door, zoals in beide gevallen, een RvT.

23 Zie voor het rapport www.governancecodezorg.nl/introductie/actueel. 
Toepasselijke governancecode

Bij gedragingen en gebeurtenissen voor 1 januari 2017 toetst de Governancecommissie aan de ZGC. ${ }^{24}$ Of na 1 januari 2017 de GCZ geldt - en waaraan wordt getoetst - is afhankelijk van de vraag of de GCZ in de betreffende zorgorganisatie al is geïmplementeerd. Daarvoor hadden zorgorganisaties het gehele jaar 2017 de tijd. De vraag aan welke governancecode getoetst dient te worden - en nader onderzoek daarnaar - is volgens de Governancecommissie niet relevant, indien de bepalingen uit de ZGC en de GCZ op een bepaald punt niet verschillen en de toetsing tot eenzelfde uitkomst leidt. ${ }^{25}$ De Governancecommissie is niet bereid om gedragingen en gebeurtenissen die zich voor 1 januari 2017 hebben voorgedaan te toetsen aan de GCZ. ${ }^{26}$ Dit lijkt mij terecht. Partijen wisten toen nog niet hoe de GCZ precies zou luiden en konden daarop niet anticiperen.

'Pas toe en leg uit'-beginsel

Een wijziging ten opzichte van de ZGC, die uitging van het 'pas toe of leg uit'27-beginsel, is dat de GGZ uitgaat van het 'pas toe en leg uit'-beginsel. De brancheorganisaties willen op een actuele en vernieuwende manier omgaan met dit beginsel, zo blijkt uit de inleiding bij de GCZ. Soms is bij toepassing juist uitleg nodig (pas toe en leg uit). Soms kan afwijking niet aan de orde zijn (pas toe!). Centraal moet weer staan de bedoeling van en de dialoog over de bepalingen, in plaats van dat de bepalingen worden 'afgevinkt', zo staat in de inleiding bij de GCZ. Van een bepaling die 'open' is geformuleerd, zal de behoefte om af te wijken minder zijn. Bij een 'gesloten' geformuleerde bepaling kan de toepassing (te) dwingend zijn. Dan kan de toepassing van het principe - in de GCZ zijn de principes, die ook nieuw zijn ten opzichte van de ZGC, leidend - waarbij de bepaling hoort, gediend zijn met een goed gemotiveerde en toetsbare onderbouwing van een alternatieve invulling, aldus de inleiding bij de GCZ. ${ }^{28}$

De Governancecommissie laat zien dit (nieuwe) beginsel serieus te nemen. ${ }^{29} \mathrm{Zij}$ toetst (steeds) of de zorgorganisatie van een bepaling mocht afwijken. Niet in alle gevallen hebben de zorgorganisaties een goede reden kunnen noemen waarom zij afweken van de GCZ. ${ }^{30}$ De vraag kan worden gesteld of externe toezichthouders zich van dit beginsel voldoende bewust zijn. ${ }^{31}$

GG 20 december 2017 (17/01) (CuraMare), overweging 4.1 en GG 20 december 2017 (17/04), GJ 2018/59 (NVZ-ActiZ/Spijkenisse Medisch Centrum), overweging 4.1.

25 GG 19 februari 2018, GJ 2018/82, overweging 4.3. Zie ook GG 16 april 2018, overweging 4.1.

26 GG 20 december 2017 (17/04), GJ 2018/59 (NVZ-ActiZ/Spijkenisse Medisch Centrum), overweging 4.1. Het argument is dat de vraag of de bedoelde gedragingen en gebeurtenissen in strijd zijn met de GCZ geen onderwerp van debat is geweest.

27 Een bepaling werd toegepast of een afwijking ervan werd goed gemotiveerd uitgelegd.

28 Inleiding op de GCZ.

29 Zie bijvoorbeeld GG 29 november 2017 (RvT GGZ), overweging 4.5, zie ook overweging 4.1 en GG 26 februari 2019, overweging 4.18 e.v. Zie ook L.G.H.J. Houwen, 'Handhaving van governancecodes: de vrijblijvendheid voorbij?', TvOB 2019, p. 46.

30 Zie bijvoorbeeld GG 4 februari 2019 (RvT FPI), overweging 4.8 en GG 26 februari 2019, overweging 4.18 e.v.

31 Wanneer de IGJ (en de NZa) bepalingen als veldnorm gebruikt, moet ermee rekening worden gehouden dat afwijken van de Code in beginsel is toegestaan. De Code is opmerkelijk genoeg door (externe) toezichthouders gaandeweg wel steeds meer als 'wet' gehanteerd, aldus B. Megens in zijn blog (www.zorgvisie.nl/blog/ metsel-de-governancecode-zorg-niet-dicht). Zie ook Houwen, Ondernemingsrecht 2020/3, p. 21. 


\section{Ontvankelijkheid}

In een aantal situaties zal de Governancecommissie een verzoeker niet-ontvankelijk verklaren. In artikel 12 lid 2 Reglement Governancecommissie (Reglement) onder a t/m e worden deze situaties opgesomd. De Governancecommissie verklaart een verzoeker nietontvankelijk wanneer een verzoeker geen belanghebbende is (zie hiervoor par. 3.1 en voor de andere situaties par. 3.2).

\subsection{Belanghebbende}

Een toetsingsverzoek bij de Governancecommissie kan alleen worden ingediend door een belanghebbende. ${ }^{32}$ Een belanghebbende is de natuurlijke of rechtspersoon die rechtstreeks bij de zorgorganisatie is betrokken en op enigerlei wijze nadeel ondervindt van de wijze van naleving van de $\mathrm{GCZ}^{33}$ door de zorgorganisatie. ${ }^{34}$

Uit de uitspraken van de Governancecommissie uit 2011-2015 bleek dat leden van de raad van bestuur (RvB), ${ }^{35}$ (ex-)werknemer(s), waaronder een oud-bestuurder, ${ }^{36}$ de ondernemingsraad, ${ }^{37}$ en brancheverenigingen ${ }^{38}$ worden gezien als belanghebbenden. Deze lijn wordt in de uitspraken in 2016-2019 doorgetrokken. Een ex-werknemer (en oudbestuurder), ${ }^{39}$ de ondernemingsraad, ${ }^{40}$ en brancheverenigingen ${ }^{41}$ zijn nog steeds belanghebbenden. Indien een branchevereniging geen belanghebbende zou kunnen zijn, zou de verplichting tot naleving van de Code voor de leden volgens de Governancecommissie 'een wassen neus' zijn. ${ }^{42}$

Uit de uitspraken van de Governancecommissie uit 2016-2019 volgt dat de kring van belanghebbende (nog) groter is. Ook een lid van de RvT kan zich wenden tot de Governancecommissie, ${ }^{43}$ evenals een RvT als orgaan. ${ }^{44}$ Dit laatste is opmerkelijk, gezien de

32 Art. 12 lid 2 onder a Reglement.

33 Er staat GCZ, maar het is handiger om hiervan Code te maken, dan hoeft bij wijziging van de toepasselijke Code ook het reglement niet steeds te worden aangepast. Dat geldt ook voor de andere bepalingen waarin wordt verwezen naar de GCZ. Art. 1 onder 1 Reglement kan dan luiden: de Code, zoals deze laatst is vastgesteld door de deelnemende brancheorganisaties.

34 Art. 1 onder 8 Reglement.

35 GG 15 mei 2013 (Integraal Kankercentrum Zuid), overweging 3.1; GG 5 december 2013, GJ 2014/62 (Humanitas), overweging 3.2.

36 GG 1 november 2011, TvGR 2012/1, m.nt. J.G. Sijmons en T.A.M. van den Ende, GJ 2012/11 (Nusantra), overweging 3.1; GG 15 mei 2013 (Integraal Kankercentrum Zuid), overweging 3.1.

37 GG 8 maart 2012 (Stichting Gehandicaptenzorg Limburg), overweging 3.3; GG 14 mei 2014 (Kraamzorg), overweging 4.1 .

38 GG 15 november 2012 (ActiZ), overweging 3.1 en GG 24 november 2015, GJ 2016/63, m.nt. A.F.H. ten Brummelhuis (GGZ Nederland/GGZ Noord-Holland-Noord), overweging 4.1.

39 Zie GG 20 december 2017 (17/01) (CuraMare), overweging 4.4 en 4.5.

40 GG 4 februari 2019 (RvT FPI).

41 GG 20 december 2017 (17/04), GJ 2018/59 (NVZ-ActiZ/Spijkenisse Medisch Centrum), overweging 4.5 en GG 26 februari 2019, GJ 2019/89, m.nt. K.D. Meersma \& B. Verkerk (ActiZ/Buurtzorg).

42 GG 20 december 2017 (17/04), GJ 2018/59 (NVZ-ActiZ/Spijkenisse Medisch Centrum), overweging 4.5.

43 GG 19 februari 2018, GJ 2018/82.

44 GG 29 november 2017 (RvT GGZ) en GG 30 september 2019. 
definitie van belanghebbende in het Reglement. Een RvT bezit geen rechtspersoonlijkheid. ${ }^{45}$ Een motivering ontbreekt in dit geval.

Ouders van cliënten zijn eveneens belanghebbenden. ${ }^{46}$ Ook als lid van de cliëntenraad zijn zij belanghebbenden in de zin van het Reglement, zo valt uit dezelfde uitspraak op te maken. ${ }^{47}$ Bovendien zijn echtgenoten en (schoon)kinderen van cliënten belanghebbenden. De Governancecommissie is van mening dat zij vanwege hun nauwe relatie met de cliënt rechtstreeks bij de stichting zijn betrokken en nadeel kunnen ondervinden van de wijze van naleving van de Code. ${ }^{48}$ De mentor van een cliënt is tevens een belanghebbende. ${ }^{49}$

Als een cliënt niet in staat is om zelf een verzoek te doen, moet een 'vertegenwoordiger' dit verzoek kunnen doen. Dit hoeft in mijn ogen niet per se een wettelijke vertegenwoordiger (mentor, bewindvoerder of curator) te zijn. Mijns inziens zou ook een niet juridisch partner, een (ander) familielid of een goede vriend een dergelijk verzoek moeten kunnen doen, mits er een (nauwe) persoonlijke band bestaat tussen de cliënt en degene die het verzoek doet. $^{50}$

De kring van belanghebbenden is echter niet onbeperkt. Het is niet de bedoeling dat het begrip belanghebbende een (te zeer) verwaterde inhoud krijgt, aldus de Governancecommissie. Een comité dat optrad als een belangenbehartiger van bezorgde burgers viel niet onder het begrip belanghebbende. ${ }^{51}$ Een sterke betrokkenheid betekent in de ogen van de Governancecommissie niet dat zij rechtstreeks bij de zorgorganisatie zijn betrokken. Daarnaast is het comité geen (formele) gesprekspartner van de RvB. Gezien de definitie in het Reglement kan ik deze uitkomst volgen. Wanneer een dergelijk comité wel een formele gesprekspartner is, kan de situatie anders liggen, zo lees ik de uitspraak. In dat geval kan gezegd worden dat een comité wel rechtstreeks bij de zorgorganisatie is betrokken. Bovendien valt uit deze uitspraak af te leiden dat de Governancecommissie niet uitsluit dat vrijwilligers, verwijzers en gemeenten ook belanghebbende kunnen zijn. ${ }^{52}$

\subsection{Overige eisen}

De Governancecommissie zal een verzoeker ook niet-ontvankelijk ${ }^{53}$ verklaren als het verzoek tot naleving van de Code niet schriftelijk kenbaar is gemaakt aan de RvB van de zorgorganisatie en er geen constructief overleg is geweest met de zorgorganisatie (en deze zo

Overigens achtte ik het niet uitgesloten dat de Governancecommissie de RvT als belanghebbende beschouwt, namelijk op dezelfde gronden dat de ondernemingsraad belanghebbende is. Zie Klaasen, TvGR 2016, p. 179.

46 GG 17 oktober 2016 (Lievegoed), overweging 3.1.

47 GG 17 oktober 2016 (Lievegoed), overweging 3.1.

48 GG 16 april 2018, overweging 4.2.

49 GG 3 januari 2017, overweging 4.1 (zie ook 2.3, de mentor was ook de broer van de cliënte).

50 Van den Ende, TvGR 2018, p. 312 wijst erop dat zorginstellingen zich van de reikwijdte bewust moeten zijn.

51 Dit comité was geen rechtspersoon, zie GG 29 oktober 2018, overweging 2.10.

52 GG 29 oktober 2018, overweging 4.4. De GG legt het begrip uit met in achtneming van (de introductie bij) 3.2 en bepaling 3.2.1 GCZ. De RvB heeft niet bepaald dat het comité 'andere belanghebbenden' zijn.

53 De Governancecommissie overweegt dat het Reglement geen aanknopingspunten biedt voor de nietontvankelijkheid op grond van rechtsverwerking (of een soortgelijke grond) in de 'private' verhouding tussen de belanghebbende en de zorgorganisatie in kwestie, zie GG 20 december 2017 (17/01) (CuraMare), overweging 4.7 en GG 19 februari 2018, GJ 2018/82, overweging 4.21. Zie hierover Van den Ende, TvGR $2018 / 4$, p. 314. 
nodig naar aanleiding daarvan maatregelen neemt). ${ }^{54}$ In de uitspraken 2016-2019 wordt duidelijk(er) wat wel en niet kan en wat de achtergrond is van deze bepaling. ${ }^{55}$ Volgens de Governancecommissie is 'de kennelijke bedoeling van het voorschrift dat een kwestie niet voortijdig ("rauwelijks") aan de Commissie wordt voorgelegd en daarmee mogelijk onnodig wordt gejuridiseerd'. Er moet in haar ogen eerst gelegenheid zijn om te bewerkstelligen dat een eventuele afwijking van de Code ongedaan wordt gemaakt. ${ }^{56}$

In de ogen van de Governancecommissie is niet voldoende in de zin van een tijdige schriftelijke mededeling wanneer de RvB vijf maanden na het ingediende verzoek bij de Governancecommissie op de hoogte wordt gebracht van een ingesteld toetsingsverzoek. De Governancecommissie stelt zich in deze situatie de vraag welke betekenis aan een tijdig verzoek aan de RvB moet worden gehecht waarin twijfel bestaat over de naleving van de Code door een ander orgaan dan het bestuur, in dit geval de RvT. ${ }^{77}$ Binnen de RvT is hierover gesproken (de verzoeker was lid van de RvT), maar dit heeft de RvT niet tot andere inzichten of gedragingen gebracht. Ook de RvB heeft niet aannemelijk gemaakt dat als de RvB wel tijdig zou zijn geïnformeerd over het voornemen tot een toetsingsverzoek, de RvB zich anders zou hebben opgesteld of tot andere besluiten zou zijn gekomen. Een beroep van de zorgorganisatie op deze eis is in de ogen van de Governancecommissie zonder belang, omdat de zorgorganisatie zich op het standpunt stelt dat zij de Code niet heeft geschonden. ${ }^{58}$ Verzoeker was ontvankelijk.

Wat als er wel schriftelijk beklag is, maar in desbetreffende brieven niet met zoveel woorden een oproep tot naleving van de Code is gedaan? Volgens de Governancecommissie kon de vraag of deze brieven kunnen gelden als schriftelijke mededeling onbeantwoord blijven doordat verweerders in geen enkel opzicht hebben erkend dat zij de Code hebben geschonden. Zij hebben geen belang bij een beroep op het Reglement, want uit het standpunt van verweerders blijkt dat intern beraad niet tot enige wijziging van het beleid of hun gedragingen zou hebben geleid. ${ }^{59}$ De weg naar de Governancecommissie ligt in een dergelijk geval open.

Het vereiste overleg (be)hoeft volgens de Governancecommissie ook niet mondeling te geschieden. Met de briefwisseling tussen partijen is voldaan aan de eis van constructief overleg. Verweerders hebben voldoende gelegenheid gehad om hun standpunt in de aan hen voorgelegde kwesties te verwoorden en waren stellig in hun overtuiging dat zij aan de Code hadden voldaan. In zo'n geval is nader overleg niet nodig en konden verzoeksters zich tot de Governancecommissie wenden voor een onafhankelijk oordeel. ${ }^{60}$

Kortom, wanneer een zorgorganisatie niet bereid is haar opstelling ten aanzien van de nietnaleving van de Code te wijzigen, ligt de lat lager. Dit ligt voor de hand omdat er kennelijk 'een derde', in casu de Governancecommissie, nodig is om haar zienswijze te geven.

54 Art. 12 lid 2 onder b Reglement.

55 In GG 8 maart 2012 (Stichting Gehandicaptenzorg Limburg), overweging 3.3, was er geen overleg geweest, maar de verzoeker (een ondernemingsraad) had dit niet geweigerd.

56 GG 19 februari 2018, GJ 2018/82, overweging 4.2.

57 GG 19 februari 2018, GJ 2018/82, overweging 4.2.

58 GG 19 februari 2018, GJ 2018/82, overweging 4.2. Zie ook GG 26 februari 2019, overweging 4.6.

59 GG 20 december 2017 (17/01) (CuraMare), overweging 4.6.

60 GG 20 december 2017 (17/04), GJ 2018/59 (NVZ-ActiZ/Spijkenisse Medisch Centrum), overweging 4.6. 
Een verzoeker is ook niet-ontvankelijk wanneer meer dan twaalf maanden zijn verstreken na het concrete voorval waarop het toetsingsverzoek betrekking heeft, zo staat in het Reglement. ${ }^{61}$ Deze termijn van twaalf maanden gaat volgens de Governancecommissie pas lopen nadat van het 'concrete voorval' melding is gemaakt in het jaardocument ${ }^{62}$ van de zorgorganisatie. Deze uitleg ligt in de ogen van de Governancecommissie 'ook hierom voor de hand, omdat derden - zoals verzoeksters [in casu brancheverenigingen; toevoeging AGHK], van veel 'concrete voorvallen' geen kennis kunnen hebben als daarover niets is vermeld in het jaardocument. Het zou ongerijmd zijn als een termijn zou kunnen aanvangen, en mogelijk zelfs zou eindigen, voordat een belanghebbende weet had (of redelijkerwijs kon hebben) van het voorval in kwestie. ${ }^{93}$ Dit uitgangspunt lijkt mij terecht.

Een toetsingsverzoek bevat een nauwkeurige omschrijving en motivering van het verzoek tot toetsing van de naleving door de betrokken zorgorganisatie van een of meer principes van de GCZ in het concreet omschreven geval, aldus het Reglement. ${ }^{64}$ Een verzoeker kan niet ontvankelijk zijn als hieraan niet wordt voldaan. Met de woorden 'een concreet omschreven geval' is volgens de Governancecommissie 'niet bedoeld dat het om een of meer welomschreven gebeurtenissen moet gaan. Als een toetsingsverzoek melding maakt van het bestaan van een - mogelijk - met de Code strijdige connectie of reglementaire voorziening', is dat voldoende. ${ }^{65}$

Meersma en Verkerk plaatsen hierbij vraagtekens. Volgens hen moet een fishing expedition niet gefaciliteerd worden en een zorginstelling moet zich kunnen verweren tegen concrete verwijten. Volgens hen vordert het belang van een verweerder dat niet iedere vraag of elk mespuntje twijfel een ontvankelijk verzoek zou moeten opleveren. ${ }^{66}$ Hoewel ActiZ, een branchevereniging, in dit geval spreekt over twijfel over de naleving, gaat het verzoek over een voldoende concrete situatie. ${ }^{67}$ Aan dat laatste moet volgens mij het meeste belang worden gehecht. Overigens had ActiZ achteraf gezien een 'constructieve communicatie' verkozen boven een gang naar de Governancecommissie, zo bleek later. ${ }^{68}$

\section{Uitspraken}

\subsection{Taak van de raad van toezicht}

Uit artikel 4.1.1 ZGC volgt wat tot de taak van de RvT wordt gerekend. De (basis)taak van de RvT is dat de RvT toezicht houdt op het besturen van de RvB en op de algemene gang

61 Art. 12 lid 2 onder e Reglement.

62 Zie voor de jaardocumenten van de verschillende verslagjaren, www.jaarverantwoordingzorg.nl/wat-enhoe/welke-gegevens-aanleveren/jaardocumenten-en-modeljaarrekeningen.

63 GG 20 december 2017 (17/04), GJ 2018/59 (NVZ-ActiZ/Spijkenisse Medisch Centrum), overweging 4.7. Zie ook GG 26 februari 2019 (ActiZ/Buurtzorg), GJ 2019/89, m.nt. K.D. Meersma \& B. Verkerk, overweging 4.3.

64 Art. 13 lid 2 onder d Reglement.

65 GG 26 februari 2019 (ActiZ/Buurtzorg), GJ 2019/89, m.nt. K.D. Meersma \& B. Verkerk, overweging 4.7.

66 Zie Meersma \& Verkerk 2019, p. 663.

67 GG 26 februari 2019 (ActiZ/Buurtzorg), GJ 2019/89, m.nt. K.D. Meersma \& B. Verkerk, 3.1.

68 P. van de Poel, 'ActiZ betreurt gang naar governance-commissie inzake Buurtzorg', Skipr 7 november 2019. Zie ook het standpunt van verweerder in GG 26 februari 2019 (ActiZ/Buurtzorg), GJ 2019/89, m.nt. K.D. Meersma \& B. Verkerk, 3.2. 
van zaken in de zorgorganisatie en dat de RvT de RvB met raad ter zijde staat. De RvT vervult de werkgeversrol voor de RvB. ${ }^{69}$ Hetzelfde staat in bepaling 6.1 en 6.5 GCZ.

Hoe wordt deze taak van de RvT nader ingevuld in de uitspraken van de Governancecommissie?

\subsubsection{Voldoende afstand tot raad van bestuur ${ }^{70}$}

Volgens de Governancecommissie is het de taak van de RvT om een evenwicht te zoeken in zijn verhouding tot de RvB en de individuele leden van de RvB, en om daarbij de nodige afstand te bewaren teneinde de toezichthoudende taak goed te kunnen vervullen. ${ }^{71}$ Onwenselijk is volgens de Governancecommissie dan ook als een persoon optreedt als de persoonlijke coach van de voorzitter van de RvB en als begeleider bij de vervulling van de vacature van voorzitter van de RvT, en later ook als begeleider bij een zelfevaluatie van de RvT. $^{72}$

Volgens de Governancecommissie houdt een RvT onvoldoende onafhankelijk en kritisch toezicht op het functioneren van de RvB als de RvT zich in zijn besluitvorming te veel laat leiden door de voorzitter van de RvB. Individueel overleg tussen de voorzitter van de RvT en de voorzitter van de RvB is begrijpelijk en vaak ook nodig, maar de RvB en de RvT dienen hierbij hun eigen verantwoordelijkheid te nemen overeenkomstig de wettelijke en statutaire taakverdeling, aldus de Governancecommissie. De RvT had in casu 'onvoldoende het essentiële evenwicht tussen de verschillende rollen van onafhankelijk toezichthouder, werkgever en adviseur van de RvB bewaakt'. ${ }^{73}$

Om de toezichtstaak (en de werkgeversrol) goed te kunnen uitvoeren is voldoende afstand nodig tussen de RvB en de RvT. Beide organen zijn daarvoor verantwoordelijk. Ook is het in mijn ogen van belang dat de RvT, om zijn (toezichthoudende) taak goed te kunnen uitvoeren, zelf een eigen oordeel vormt en zich niet (al te veel) laat leiden (door de voorzitter van) de RvB.

Uit deze casus blijkt dat een voorzitter van de $\mathrm{RvT}^{74}$ voldoende tegenspel moet kunnen bieden aan de voorzitter van de RvB. ${ }^{75}$ De voorzitter van de RvT en de voorzitter van de RvB vormen samen een onmisbare schakel tussen het bestuur en de raad. ${ }^{76}$ In een zelfevaluatie zou de relatie tussen beide voorzitters aan de orde moeten komen, omdat deze van

69 Art. 4.4.1 ZGC.

70 In GG 16 april 2018 hebben verzoekers geen concrete voorbeelden van onvoldoende professionele distantie tussen de voorzitter van de RvT en de beide leden van de RvB ingebracht (overweging 4.22).

71 GG 20 december 2017 (17/01) (CuraMare), overweging 4.12. Zie ook GG 20 december 2017 (17/04), GJ 2018/59 (NVZ-ActiZ/Spijkenisse Medisch Centrum), overweging 4.11.

72 GG 20 december 2017 (17/01) (CuraMare), overweging 4.12. Zie ook GG 20 december 2017 (17/04), GJ 2018/59 (NVZ-ActiZ/Spijkenisse Medisch Centrum), overweging 4.11.

73 GG 20 december 2017 (17/01) (CuraMare), overweging 4.18. Dit leidt tot schending van art. 2.1.3 en 4.1.1 ZGC.

74 De bevoegdheden en verantwoordelijkheden van de RvT komen volgens de Governancecommissie toe aan deze raad in zijn geheel. Er is niet een 'eigen' domein voor een dagelijks bestuur (of agendaoverleg). Zie GG 19 februari 2018, GJ 2018/82, overweging 4.16 en 4.26.

75 Zie ook S.R. Schuit \& C. Jaspers, 'De gewijzigde takopvattingen van commissarissen en hun voorzitter', Ondernemingsrecht 2017/71, p. 424.

76 In de literatuur aangeduid als linking pin, zie hierover Schuit \& Jaspers, Ondernemingsrecht 2017/71, p. 422 en C.F. Perquin-Deelen, 'Gedrag binnen de meerhoofdige RvB en RvC', Ondernemingsrecht 2019/82, p. 448. 
invloed is op het goed functioneren van beide organen. De boardroom dynamics waren in deze casus kennelijk niet optimaal.

In de praktijk kan de voorzitter van de RvB de voorzitter van RvT wel als klankbord gebruiken. Hierbij zal de voorzitter van RvT de bestuurder vooral vragen moeten stellen in plaats van een oordeel te geven. Belangrijk advies voor de RvT is voldoende afstand te bewaren tot de RvB en zich bewust zijn van het belang hiervan. Overigens geldt dit andersom ook.

\subsubsection{Evaluatie functioneren van de raad van toezicht}

De RvT evalueert zijn functioneren ten minste jaarlijks buiten de aanwezigheid van de RvB en informeert de RvB over de uitkomsten hiervan, zo stond in de ZGC. ${ }^{77}$ De GCZ bepaalt hetzelfde, maar voegt daaraan toe dat de RvT zorgt voor vastlegging van de uitkomsten daarvan. De RvT stelt zich van tevoren op de hoogte van de visie van de RvB op het functioneren van de RvT. Ten minste eenmaal per drie jaar wordt deze evaluatie door een onafhankelijke externe deskundige begeleid. ${ }^{78}$

In situaties waarin een organisatie in een onrustige periode is beland, met wisselingen in de RvT (en andere kwesties), is periodieke zelfreflectie van de RvT van wezenlijke betekenis, aldus de Governancecommissie. ${ }^{79}$ Het is van belang dat de RvT deze taak om te evalueren serieus neemt. ${ }^{80}$ Een evaluatie(moment ${ }^{81}$ zorgt ervoor dat met een bepaalde afstand de ontstane situatie nog eens een keer kan worden belicht.

Om de 'emoties' uit de discussie te halen is het wenselijk dit te doen onder begeleiding. ${ }^{82}$ Afhankelijk van de situatie kan het aan te bevelen zijn om dit vaker te doen dan eens in de drie jaar. Begeleiding kan belangrijk zijn wanneer tijdens de RvT-vergaderingen blijkt dat de RvT-leden niet (voldoende) op één lijn zitten of de RvT en de RvB elkaar niet (lijken te) begrijpen.

77 Art. 4.1.6 ZGC.

78 Bepaling 7.3.1 GCZ. Vgl. bepaling 4.1.5 GCZ. De RvT en RvB voeren ten minste eenmaal per twee jaar, desgewenst onder leiding van een externe deskundige, een gesprek over hun onderlinge samenwerking en leggen de resultaten daarvan vast.

79 GG 20 december 2017 (17/01) (CuraMare), overweging 4.9. Ook werden geen evaluaties gehouden met de (leden van de) RvB. Door geen jaarlijkse evaluaties te houden nam de RvT onvoldoende afstand tot (de voorzitter van) de RvB om zijn toezichthoudende rol goed te kunnen vervullen. Dit leverde schending op van art. 4.1.4 en 4.1.7 ZGC. Zie ook Hof Amsterdam (OK) 2 november 2015, JOR 2016/61, m.nt. P. van Schilfgaarde (Meavita).

80 Dit hoeft niet per se tijdens de jaarlijkse zelfevaluatie. Gezag moet verdiend worden, daarom moet de raad zichzelf op dit punt voortdurend kritisch blijven beoordelen, aldus Schuit \& Jaspers, Ondernemingsrecht $2017 / 71$, p. 422.

81 Zie over de vormgeving van de zelfevaluatie, Perquin-Deelen, Ondernemingsrecht 2019/82, p. 452-453.

82 Zie over de omgang tussen een voorzitter van de RvT en een lid, GG 19 februari 2018, GJ 2018/82, overweging 4.9-4.12. De voorzitter mag bijvoorbeeld een lid op het 'thuisnummer' bellen als het lid via de mobiele telefoon onbereikbaar is. 


\subsubsection{Vereiste informatie bij de benoeming van bestuurder}

De RvT vervult de werkgeversrol voor de RvB en is verantwoordelijk voor de benoeming van bestuurders. Ook gaat de RvT over de rechtspositie en de andere arbeidsvoorwaarden van de individuele leden van de RvB, zo blijkt uit de ZGC en GCZ. ${ }^{83}$

Het benoemen van de bestuurders is een van de kerntaken van de RvT, aldus de Governancecommissie. Het gaat om een bevoegdheid die aan de RvT als geheel toekomt. ${ }^{84}$ Elk lid van de RvT moet dus de beschikking (kunnen) hebben over de informatie die nodig is om zijn taak te kunnen uitoefenen. ${ }^{85}$ Leden van de RvT dienen volgens de Governancecommissie 'volledige zeggenschap te hebben' over de wijze waarop de RvT de selectie- en benoemingsprocedure (van een bestuurder) inricht en hoe zij de beschikking krijgen over de noodzakelijke informatie over de kandidaten. ${ }^{86}$

Wanneer een (interne) kandidaat (voor het bestuurderschap) de resultaten van een (ontwikkel)assessment (die op eigen initiatief heeft plaatsgevonden) buiten de selectieprocedure wil houden en niet beschikbaar wil stellen aan de gehele selectiecommissie, dient een voorzitter van de RvT hierover duidelijkheid te verschaffen. De selectiecommissie kan dan zelf besluiten of zij genoegen neemt met deze mededeling, alsnog een selectieassessment verlangt of een andere oplossing kiest, aldus de Governancecommissie. ${ }^{87}$ Een lid van de RvT heeft recht op de (gehele) tekst van de arbeidsovereenkomst met de (nieuwe) bestuurder. Volgens de Governancecommissie hoeft een lid van de RvT geen genoegen te nemen met een opsomming van de hoofdpunten. ${ }^{88}$

De RvT kan ervoor kiezen slechts een aantal leden van de RvT deel te laten uitmaken van de selectiecommissie. Hierover dient dan wel verantwoording te worden afgelegd aan de andere RvT-leden. ${ }^{89}$ De tekst van de arbeidsovereenkomst met de bestuurder dient voor elk RvT-lid beschikbaar te zijn. Dit behoort tot de essentiële informatie in het kader van de werkgeversrol. In casu werd er zelfs nadrukkelijk om gevraagd. De voorzitter van de RvT heeft, als verantwoordelijke voor het functioneren van de RvT, ${ }^{90}$ ervoor te zorgen dat geen enkel lid wordt buitengesloten. ${ }^{91}$ In dit kader kan het ook wenselijk zijn voor de selectieprocedure van een bestuurder een derde in te schakelen, die de begeleiding van het proces

83 Art. 4.1.1 ZGC en art. 3.2.2 ZGC (tenzij de bevoegdheid bij de algemene vergadering berust) en bepaling 6.5.2 GCZ.

84 GG 19 februari 2018, GJ 2018/82, overweging 4.16. De benoeming van een (bouw)directeur behoort tot de bevoegdheden en verantwoordelijkheden van de RvB, zie overweging 4.23.

85 Zie art. 4.1.8 ZGC en bepaling 6.4.3 GCZ.

86 GG 19 februari 2018, GJ 2018/82, overweging 4.16.

87 GG 19 februari 2018, GJ 2018/82, overweging 4.18.

88 GG 19 februari 2018, GJ 2018/82, overweging 4.19.

89 Gezien zijn bijzondere functie bij de samenstelling van het bestuur is de voorzitter van de RvC vaak tevens de voorzitter van de selectie- en benoemingscommissie, zie S.R. Schuit en C. Jaspers, 'De gewijzigde taakopvattingen van commissarissen en hun voorzitter', Ondernemingsrecht 2017/71, p. 422.

90 Dit blijkt duidelijk uit de Nederlandse Corporate Governance Code (bijv. best practice, bepaling 2.3.6) en bijna niet uit de GCZ (alleen bepaling 2.6.1). De rol van de voorzitter verdient meer aandacht, zie A.G.H. Klaassen, 'Moeten toezichthouders wakker liggen van de Meavita-uitspraak van de Ondernemingskamer?', TvT 2016, p. 44.

91 Zie hierover ook B.F. Assink, 'Facetten van verantwoordelijkheid in hedendaags ondernemingsbestuur', in: B.F. Assink \& D.A.M.H.W. Strik, Ondernemingsbestuur en risicobeheersing op de drempel van een nieuw decennium: een ondernemingsrechtelijke analyse (Preadvies van de Vereeniging Handelsrecht), Deventer: Kluwer 2009, p. 97 e.v. 
op zich neemt. De RvT kan dan geen 'stap' vergeten en kan zich richten op het selecteren van de juiste kandidaat voor 'zijn' zorgorganisatie.

\subsubsection{Naleving van wet- en regelgeving en de Code}

De RvT houdt ten minste toezicht op de naleving van wet- en regelgeving. ${ }^{92}$ In de GCZ wordt dit niet expliciet genoemd. ${ }^{93}$ Volgens de Governancecommissie behoort hiertoe de interne regelgeving, zoals vastgelegd in de statuten ${ }^{94}$ en reglementen. ${ }^{95}$ Statuten en reglementen bepalen de interne organisatie van een rechtspersoon. ${ }^{96} \mathrm{Om}$ die reden dient de RvT toe te zien op de naleving daarvan.

De RvT is ook verantwoordelijk voor de naleving van de Code. ${ }^{97}$ Een RvT die die geen uitleg geeft over de afwijking van de Code schendt de Code op dit punt. ${ }^{98}$ Van schending is ook sprake wanneer een (nieuwe) RvT betrokken is bij de afronding van het jaardocument, waarin veel kennelijke onjuistheden staan en geen enkel toelichting is gegeven over afwijkingen van de Code. Dit had de RvT moeten opvallen, temeer omdat een van de leden ook lid was van de 'oude' RvT.99

\subsubsection{Collectief aftreden van de raad van toezicht}

De Governancecommissie acht het in strijd met de taak van een RvT (toezicht houden op het besturen van de RvB en zijn werkgeversrol voor de RvB) om collectief af te treden. ${ }^{100}$ Volgens de Governancecommissie staat het een individueel lid van een RvT 'vrij om zijn functie neer te leggen als hij zich niet langer verantwoordelijk wil houden voor de wijze waarop de instelling in kwestie functioneert, maar een RvT schiet in zijn verplichtingen op grond van de Code tekort als hij collectief aftreedt zonder zijn verantwoordelijkheid voor een juiste vorm van toezicht te nemen'. In casu was de gehele RvT afgetreden omdat de RvB niet van koers wenste te veranderen. De gehele RvT trad af ten tijde van een crisis voordat er nieuwe RvT-leden waren benoemd en (meer in het algemeen) voordat de continuiteit van de stichting was gewaarborgd. ${ }^{101}$

Denkbaar is dat deze situatie een aantal vragen oproept. Waarom heeft de RvT de bestuurder niet ontslagen? Dit zou ermee te maken kunnen hebben dat de bestuurder de initiatiefneemster was van de stichting. Hoe zit het met de benoeming van de nieuwe leden

93 Vgl. bepaling 6.1 GCZ.

94 GG 20 december 2017 (17/01) (CuraMare), overweging 4.10. In casu bestond de RvT uit een even aantal leden, terwijl de statuten bepaalden dat de RvT uit een oneven aantal moest bestaan, er was geen sprake van een noodsituatie die eventueel een afwijking rechtvaardigde voor een korte periode.

95 GG 20 december 2017 (17/01) (CuraMare), overweging 4.11.

96 Zie Van der Heijden/Dortmond, Handboek voor de naamloze en de besloten vennootschap, Deventer: Kluwer 2013/49 en Asser/Maeijer \& Kroeze, De rechtspersoon 2-I*, Deventer: Wolters Kluwer 2015, p. 184.

97 Art. 2.1.3 ZGC en bepaling 4.1.1 GCZ. De RvT is ook verantwoordelijk voor de governancestructuur. Dit geldt overigens ook voor de RvB.

98 GG 20 december 2017 (17/01) (CuraMare), overweging 4.13 en GG 20 december 2017 (17/04), GJ 2018/59 (NVZ-ActiZ/Spijkenisse Medisch Centrum), overweging 4.9.

99 GG 3 januari 2017, overweging 4.7.

100 De Governancecommissie verwijst naar art. 4.1.1 ZGC.

101 GG 3 januari 2017, overweging 4.3. 
van de RvT? In casu kon op grond van de statuten de bestuurder de nieuwe leden benoemen.

In het algemeen kan collectief aftreden als ongewenst worden gezien, omdat de RvT juist de taak heeft in te grijpen als het mis gaat en de RvT bij een stichting meestal zijn eigen leden benoemt. In dit kader is het van belang dat één van de leden aanblijft om een nieuwe RvT te kunnen vormen. De RvT is dan verantwoordelijk voor zijn opvolging. ${ }^{102}$

Individueel aftreden kan gewenst of vereist zijn indien een lid van de RvT zijn toezichthoudende functie niet langer kan uitoefenen zoals hij of zij dat graag ziet. Of zoals de Governancecommissie overweegt, als hij zich niet langer verantwoordelijk wil houden voor de wijze waarop de instelling in kwestie functioneert. Daarnaast dient een RvT-lid af te treden als hij of zij een gebrek aan tijd of deskundigheid heeft om zijn functie te kunnen uitoefenen. ${ }^{103}$

\subsection{Geen bestuurstaken}

In de ZGC staat dat leden van de RvT nimmer taken verrichten van de RvB. In de toelichting staat dat het vervullen van bestuurstaken door een of meer (gedelegeerde) toezichthouders is uitgesloten. ${ }^{104}$ Bij ontstentenis ${ }^{105}$ van de RvB dient op andere wijze in het bestuur te worden voorzien. ${ }^{106}$ In de GCZ staat dat de RvT of zijn afzonderlijke leden geen verantwoordelijkheden en bevoegdheden van de RvB overnemen en niet de bestuursfunctie vervullen. ${ }^{107}$

Onder omstandigheden kan, ook al is sprake van schending van dit artikel, toch een toereikende uitleg worden gegeven voor de noodzaak van deze schending. Volgens de Governancecommissie is hiervan sprake als de RvT iets meer dan twee weken bestuurstaken uitvoert wanneer er onrust in de zorgorganisatie is ontstaan door dat de (vorige) RvT collectief is afgetreden, drie (andere) sleutelfiguren zijn ontslagen en de (enig) bestuurder ziekteverlof heeft. Reden hiervoor is dat de RvT tijd nodig heeft 'om de situatie te analyseren, zich te beraden op de vereiste maatregelen en de juiste persoon als interim-bestuurder voor deze specifieke organisatie te vinden'. Bovendien is deze situatie uitgelegd aan de stakeholders en die hebben daarmee ingestemd. ${ }^{108}$

Opmerkelijk is dat de gehele RvT bestuurstaken heeft verricht en niet slechts één lid (of twee leden). Er was in deze casus duidelijk sprake van rolvermenging. De toezichthoudende taak (van de RvT) kon niet effectief worden vervuld. Deze twee bezwaren van de Governancecommissie tegen een dergelijke situatie bleken uit de uitspraken in de periode

102 Zie over collectief aftreden ook A. Hendrikse, 'De commissaris in crisis: code geel, oranje of rood?', TOP 2014/379 en de genoemde jurisprudentie.

103 Zie ook Hendrikse, TOP 2014/379.

104 Art. 4.4.3 ZGC. Zie in dit kader ook Klaassen, TvGR 2016, p. 185.

105 Anders dan in het wetsvoorstel Wet Bestuur en Toezicht Rechtspersonen (WBTR, Kamerstukken II 2015/16, 34491, nr. 2) is bij de nota van wijziging (nr. 7) de ontstentenis en belet regeling niet opgenomen voor andere rechtspersonen dan de nv en de bv.

106 Het verdient aanbeveling dat de RvT bij reglement regelt wat er dient te gebeuren bij ontstentenis van de gehele RvB, waarbij de RvT de duur van de alsdan te treffen tijdelijke voorzieningen vastlegt. Zie in deze ook art. 3.2.3 ZGC.

107 Bepaling 4.1.3. GCZ.

108 GG 3 januari 2017, overweging 4.10. 
2011-2015. ${ }^{109}$ Wanneer één lid de bestuurstaak tijdelijk op zich neemt, kunnen de andere leden van de RvT daarop nog (enigszins) toezicht houden. Mijn aanbeveling is om deze situatie van ontstentenis van het bestuur bij voorbaat al te regelen en iemand uit het management (indien aanwezig) met de bestuurstaak te belasten. ${ }^{110}$

Gezien de omstandigheden getuigt deze uitspraak van de Governancecommissie wel van 'feeling' met de praktijk. Soms is een situatie zo uitzonderlijk dat naar bevind van zaken moet worden gehandeld. Als dit goed wordt uitgelegd en instemming heeft van de stakeholders, zou daartegen minder bezwaar moeten zijn, maar de schoonheidsprijs verdient een dergelijke oplossing niet.

\subsection{Openbare werving van leden van de raad van toezicht ${ }^{111}$}

Leden van de RvT worden geworven via een openbare procedure, zo volgt zowel uit de ZGC als de GCZ. ${ }^{112}$

Wanneer aan een dergelijke procedure wordt deelgenomen door een of meer kandidaten van wie de namen door een lid van de RvB of van de RvT zijn genoemd, is dit volgens de Governancecommissie niet in strijd met de Code. Voorwaarde is wel dat deze kandidaten op gelijke voet meedingen als eventuele andere kandidaten en binnen het vastgestelde profiel passen. ${ }^{113}$

Personen uit het netwerk van leden van de RvB of RvT hoeven inderdaad geen probleem te zijn, mits zij langs dezelfde meetlat worden gelegd. Het is in mijn ogen niet wenselijk wanneer alle kandidaten uit het eigen netwerk komen, daarom is openbare werving zo belangrijk. De kring van geschikte kandidaten dient zo ruim mogelijk te zijn.

Er kan afgeweken worden van deze bepaling, mits deze afwijking voldoende wordt uitgelegd. Daarvan was in beide volgende gevallen geen sprake. ${ }^{114}$ De uitleg dat er sprake is van een noodsituatie, omdat in casu de gehele 'oude' RvT was afgetreden en op korte termijn voorzien moest worden in een 'nieuwe' RvT, werd niet geaccepteerd door de Governancecommissie. De noodsituatie was ontstaan door het aftreden van de gehele RvT, wat op zich al een schending van de Code is. ${ }^{115}$

Ook werd niet door de Governancecommissie geaccepteerd dat de RvT zonder (bijzondere) redenen en zonder de belanghebbenden daarover te informeren heeft gekozen voor een andere wervingsprocedure dan oorspronkelijk was gecommuniceerd met de ondernemingsraad en de cliëntenraad. Oorspronkelijk zou worden gekozen voor een 'romp'-RvT van drie leden als tijdelijke oplossing. Het vierde lid (van de RvT) zou dan

109 Zie GG 15 mei 2013 (Integraal Kankercentrum Zuid), overweging 3.11 en GG 5 december 2013, GJ 2014/62 (Humanitas), overweging 3.6.

110 Zie mijn noot onder Hof Den Bosch 30 oktober 2018, JOR 2019/99, m.nt. A.G.H. Klaassen. Dit is een vervolg op Rb. Limburg 12 november 2014, JOR 2015/322, m.nt. L.H.G.J. Houwen, waarin wordt verwezen naar GG 8 maart 2012. Zie ook Klaassen, TvGR 2016, p. 185.

111 De selectie van de voorzitter van de RvT dient objectief, transparant en onafhankelijk van de RvB plaats te vinden. Zie GG 20 december 2017 (17/01) (CuraMare), overweging 4.13 en GG 20 december 2017 (17/04), GJ 2018/59 (NVZ-ActiZ/Spijkenisse Medisch Centrum), overweging 4.9.

112 Art. 4.2.8 ZGC en bepaling 6.2.4 GCZ.

113 GG 19 februari 2018, GJ 2018/82, overweging 4.7. Zie ook overweging 4.6. De voorzitter van de RvT mag namen noemen voor een zetel in de RvT.

114 In beide gevallen ging het om art. 4.2.8 ZGC.

115 GG 3 januari 2017, overweging 4.5. Zie ook par. 4.1.5. 
worden benoemd na openbare werving. Dit scenario van een rompbezetting zou te rechtvaardigen zijn, omdat in geval van een financiële noodsituatie een weinig kostbare, voortvarende wervingsprocedure nodig kan zijn, zo erkent de Governancecommissie. Daarnaast is geen uitleg gegeven over waarom is afgeweken van de Code in de jaardocumenten. ${ }^{116}$

\subsection{Onafhankelijkheid van leden van de raad van toezicht}

De RvT is zodanig samengesteld dat de leden ten opzichte van elkaar, de RvB en welk deelbelang dan ook onafhankelijk en kritisch kunnen opereren, zo stond in de ZGC. ${ }^{117}$ Dit vloeit voort uit het Uitvoeringsbesluit WTZi. ${ }^{118}$ De GCZ verwijst naar het Uitvoeringsbesluit WTZi en bepaalt verder dat de leden van de RvT geen vertegenwoordiger zijn van enige interne of externe partij en dat zij handelen zonder last of ruggenspraak. Zij dienen te kijken met een brede blik, zich bewust van de maatschappelijke positie van de zorgorganisatie. $^{119}$

Verder staat in de ZGC en de GCZ dat de RvT ook leden op bindende voordracht kan benoemen. Deze (voorgedragen) leden moeten ook onafhankelijk van de voordragende partij kunnen functioneren. ${ }^{120}$

Van onafhankelijk toezicht door een RvT-lid is geen sprake wanneer een werknemer van een hoofdaannemer lid van de RvT is bij de onderaannemer (in casu de stichting). Daarbij kwam dat een directeur bij de onderaannemer ook in dienst is van de hoofdaannemer. Er bestaat te veel twijfel of, ondanks de gemaakte afspraken, het RvT-lid in deze situatie objectief en onafhankelijk kan functioneren binnen de RvT en ten opzichte van de directeur binnen de onderaannemer (stichting) en hoofdaannemer. Volgens de Governancecommissie hebben de hoofdaannemer en de onderaannemer botsende belangen. ${ }^{121} \mathrm{Ik}$ vat deze overweging zo op dat het RvT-lid in dit geval niet onafhankelijk is van een bepaald deelbelang.

De onafhankelijkheid van een voorgedragen RvC-lid komt in het geding wanneer een werknemer, ${ }^{122}$ die in een afhankelijkheidsrelatie staat tot een indirect aandeelhouder van de zorgorganisatie, op voordracht (van de aandeelhouder) tot lid van de $\mathrm{RvC}$ (van die zorgorganisatie) wordt benoemd. In de ogen van de Governancecommissie moet de onafhankelijkheid waarborgen dat het toezichthoudend orgaan in vrijheid, en dus ook los van enige binding aan het bestuur of de aandeelhouders, zijn taak in het belang van de

116 GG 17 oktober 2016 (Lievegoed), overweging 3.4.

117 Art. 4.4.1 ZGC.

118 Zie art. 6.1 Uitvoeringsbesluit WTZi.

119 Introductie op onderdeel 6.2 GCZ. Ook wordt verwezen naar Principe 2.

120 Art. 4.4.2 ZGC en bepaling 6.3.1 GCZ. Zij moeten ook voldoen aan de statutaire (kwaliteits)eisen en de vastgestelde profielschets.

121 GG 17 oktober 2016 (Lievegoed), overweging 3.7. Een adviserende rol buiten de RvT had volgens de Governancecommissie meer in de rede gelegen.

122 Volgens de Governancecommissie kon in het midden blijven of deze persoon directeur of statutair bestuurder was, zie GG 4 februari 2019 (RvT FPI), overweging 4.4. Ik denk dat dit in casu inderdaad geen invloed zou hebben gehad. 
zorgorganisatie ${ }^{123}$ kan uitvoeren. ${ }^{124}$ De $\mathrm{RvC}$ heeft geen uitleg kunnen geven waarom een afwijking van de Code op haar plaats zou zijn. ${ }^{125}$ Het (voorgedragen) RvC-lid kan eventueel 'onder druk worden gezet' door hem als werknemer bij een andere bv te ontslaan. Daardoor kan het RvC-lid niet onafhankelijk van een deelbelang (in casu van de aandeelhouder) functioneren.

De onafhankelijkheid van de leden van de RvT ten opzichte van elkaar is niet in het geding als twee vrienden, die daarnaast ook werken bij dezelfde organisatie (een debatclub), ${ }^{126}$ in één RvT zitten, wanneer daarover openheid bestaat. De Governancecommissie erkent dat deze omstandigheid een beeld kan opleveren waarin twijfel kan ontstaan over de onafhankelijkheid van beiden ten opzichte van elkaar. ${ }^{127}$ Het zal afhangen van het karakter van de personen of sprake is van (voldoende) onafhankelijkheid. ${ }^{128}$

De Governancecommissie lijkt bij deze uitspraken ${ }^{129}$ de onafhankelijkheid van de leden van de RvT te interpreteren als onafhankelijkheid in $\operatorname{mind}(\text { set })^{130}$ Bij deze vorm van onafhankelijkheid gaat het om een neutrale opstelling ten opzichte van deelbelangen (of elkaar) en het in staat zijn om onbeïnvloed een oordeel te (kunnen) vormen.

Naast deze vorm van onafhankelijkheid bestaat er ook de onafhankelijkheid in appearance en de onafhankelijkheid in state ${ }^{131} \mathrm{Bij}$ onafhankelijkheid in appearance gaat het om de indruk ten opzichte van een derde. Daarom dient waarschijnlijk ook de schijn van belangenverstrengeling te worden voorkomen (zie hierover par. 4.5). Onafhankelijkheid in state houdt in dat een RvT-lid volgens formele criteria onafhankelijk is. Bepaalde functies of

123 Zie over dit onderwerp A.G.H. Klaassen, 'Vennootschappelijk belang en organisaties in de gezondheidszorg - een staaltje acrobatiek in de bestuurskamer?', in: B. Kemp, H. Koster \& C.A. Schwarz, De betekenis en functies van het vennootschappelijk belang (Instituut voor Ondernemingsrecht deel 115), Deventer: Wolters Kluwer 2019, p. 270 e.v.

124 GG 4 februari 2019 (RvT FPI), overweging 4.7. Partijen gingen er in deze casus van uit dat de bepalingen in de Code ook van toepassing zijn op een RvC bij een bv. Ook de Governancecommissie neemt dit tot uitgangspunt, omdat de RvC immers toezichthoudende taken van vergelijkbare aard heeft als een RvT, zie overweging 4.2.

125 De RvC voert vier argumenten aan, deze worden afgewezen; zie GG 4 februari 2019 (RvT FPI), overweging 4.8 .

126 De Governancecommissie gaat ervan uit dat de organisatie een soort debatclub is en geen zakelijk netwerk waarin (potentiële) opdrachten verdeeld of doorgeschoven worden.

127 GG 17 oktober 2016 (Lievegoed), overweging 3.10.

128 M.J. Kroeze, 'Onafhankelijkheid van commissarissen', Ondernemingsrecht 2005/92.

129 Hierbij dient te worden aangetekend dat de verschillende vormen van onafhankelijkheid niet altijd strikt kunnen worden gescheiden (zie ook par. 4.5). Zie GG 17 oktober 2016 (Lievegoed). Verzoekers verzochten om toetsing van art. 4.4 (onafhankelijkheid) en art. 4.5 (belangenverstrengeling) van de ZGC.

130 Ook wel aangeduid als onafhankelijkheid in fact.

131 Zie over de verschillende facetten en betekenissen van onafhankelijkheid, N.J.M. van Zijl, The importance of Board Independence. A Multidisciplinary Approach, Deventer: Kluwer 2012 en M.J. van Uchelen-Schipper, De rol en positie van de raad van toezicht van de stichting, (Instituut voor Ondernemingsrecht deel 112) (diss. Utrecht), Deventer: Wolters Kluwer 2018, p. 404 e.v. Zie ook het standpunt van DNB, www.dnb.nl/nieuws/ nieuwsoverzicht-en-archief/dnbulletin-2012/dnb278277.jsp. 
omstandigheden zijn onverenigbaar met het zijn van RvT-lid. Een voorbeeld hiervan zijn de eisen die genoemd worden in de toelichting bij artikel 6.1 Uitvoeringsbesluit WTZi. ${ }^{132}$

\subsection{Belangenverstrengeling van leden van de raad van toezicht}

Elke vorm of schijn van persoonlijke bevoordeling dan wel belangenverstrengeling tussen enig lid van de RvT en de zorgorganisatie moet worden vermeden, zo staat in de ZGC en GCZ. ${ }^{133}$ De ZGC en GCZ noemen hiervan een concreet voorbeeld. Een lid van de RvT kan niet tegelijkertijd de functie vervullen van een lid van de RvB of de RvT van een andere zorgorganisatie die binnen het verzorgingsgebied van de zorgorganisatie geheel of gedeeltelijk dezelfde werkzaamheden als de zorgorganisatie verricht. ${ }^{134}$

Volgens de Governancecommissie levert de situatie dat een persoon als voorzitter van de RvT bij een stichting wordt benoemd die vrij kort daarvoor interim-bestuurder was van een coöperatie waarin die stichting als lid participeerde de schijn van belangenverstrengeling op. Bovendien bestond een zakelijke relatie met de voorzitter van de RvB. ${ }^{135}$ In de ogen van de Governancecommissie levert ook de (volgende) situatie de schijn van belangenverstrengeling op wanneer een persoon wordt benoemd als lid van de RvT (van een stichting) die daarvoor (interim-)bestuurder was van een zakelijk partner waarmee de stichting een conflict had. Er zat een (te) korte tijd tussen de (beëindiging van de) zakelijke relatie en de benoeming. ${ }^{136}$

De Governancecommissie lijkt steeds in gedachten te houden dat een (redelijk handelende en geïnformeerde) derde niet de indruk moet kunnen hebben dat de onafhankelijkheid van de leden van de RvT in het geding is, of te wel de onafhankelijkheid in appearance (zie ook par. 4.4). ${ }^{137}$ In die zin kan ik de Governancecommissie volgen.

De Governancecommissie heeft minder moeite met de volgende situaties. Er is geen sprake van belangenverstrengeling wanneer een persoon wordt benoemd in de RvT van een stichting, die lid is van een coöperatie die een zorgorganisatie in stand houdt en de activiteiten heeft overgenomen van een (andere) failliete stichting, waar deze zelfde persoon tien jaar lid van de RvT is geweest. De Governancecommissie ziet hierin geen probleem omdat de verbinding tussen de (eerste) stichting met de zorgorganisatie pas is ontstaan ruim na de

132 Stb. 2007, 461, p. 8/9. Zie ook www.wtzi.nl/aanvragen/aanvragen-toelatingen-rechtspersonen. Deze eis wordt opgenomen in art. 3 lid 1 onder c Wtza (nieuw); zie hierover A.G.H. Klaassen, 'Statutaire inrichting van zorginstellingen en het wetsvoorstel Wet toetreding zorgaanbieders', WPNR 2018 (7192), p. 367.

133 Art. 4.5.1 ZGC en bepaling 2.6.1 GCZ. Vgl. Hof Amsterdam 30 april 2018, JOR 2018/211, m.nt. A.F.J.A. Leijten (DeSeizoenen), r.o. 3.31 (en r.o. 3.21).

134 Tenzij de andere zorgorganisatie als groeps- of dochtermaatschappij of anderszins nauw verbonden is met de zorgorganisatie, zie bepaling 2.6.2 GCZ en art. 3.3.2 en 4.4.4 ZGC.

135 GG 20 december 2017 (17/01) (CuraMare), overweging 4.13. Daarnaast was er contact geweest met de voorzitter van de RvB over deze functie. De Governancecommissie achtte deze situatie ook in strijd met art. 2.1.3 en 4.1.1 ZGC. Zie ook GG 20 december 2017 (17/04), GJ 2018/59 (NVZ-ActiZ/Spijkenisse Medisch Centrum), overweging 4.9 .

136 GG 20 december 2017 (17/01) (CuraMare), overweging 4.15. Overigens betrof het een benoeming voor de totstandkoming van de ZGC en kon hieraan niet getoetst worden.

137 De schijn van belangenverstrengeling kan afbreuk doen aan het vertrouwen in de zorgorganisatie, zo staat in de introductie bij bepaling 2.6 GCZ. 
benoeming van deze persoon. ${ }^{138}$ Bovendien overlapten de verzorgingsgebieden van beide stichtingen elkaar niet. ${ }^{139}$

Er is geen sprake van belangenverstrengeling (of de schijn daarvan) als het bedrijf van de broer van de voorzitter van een RvT wordt genoemd in uitnodigingen die het bedrijf ter beschikking heeft gesteld voor een verkoping op het terrein van de instelling van de stichting. Dit is van te gering gewicht en er is geen sprake van persoonlijk voordeel van de RvTvoorzitter. ${ }^{140}$

In dezelfde categorie valt de volgende situatie. Het wordt als onhandig gezien als op de website van het bedrijf van de voorzitter van de RvT projecten worden vermeld waarbij mogelijk op enig moment de stichting waar deze persoon is benoemd betrokken is geweest. Het gaat om oude en ook toen slechts potentiële verbanden, die alle dateren van voor de benoeming tot RvT-lid. Zoals de Governancecommissie als advies geeft, 'het was beter geweest als deze achterhaalde teksten zouden zijn verwijderd toen de betrokkene toetrad tot de RvT', ${ }^{141}$

Een zekere alertheid mag van de RvT worden verwacht, zodat de derde niet op het verkeerde been kan worden gezet. Als advies van mijn kant, websites van zorgorganisaties met gegevens over relevante nevenfuncties (van de leden van de RvT) dienen ook actueel te zijn. ${ }^{142}$

Hoewel elke schijn van belangenverstrengeling moet worden vermeden en leden van een RvT zich daarvan bewust moeten zijn, levert volgens de Governancecommissie niet elke netwerkrelatie of persoonlijke bekendheid (met elkaar) schending van de Code op. ${ }^{143}$ Bij een zeer strikte toepassing zou het heel moeilijk worden om in de zorgsector raden van toezicht te formeren, aldus de Governancecommissie. ${ }^{144}$ Dit getuigt mijns inziens van realiteit. In een sector waar meerdere personen verschillende functies uitoefenen ligt het voor de hand dat men elkaar soms in ander verband heeft leren kennen.

Zoals gezegd, kan een lid van RvT niet tegelijkertijd de functie vervullen van een lid van de RvB of de RvT van een andere zorgorganisatie die binnen het verzorgingsgebied van de zorgorganisatie geheel of gedeeltelijk dezelfde werkzaamheden als de zorgorganisatie verricht, zo staat in bepaling 2.6.2 GCZ. ${ }^{145}$ Volgens de Governancecommissie heeft deze bepaling een 'gesloten' karakter. Dit is een harde norm, die niet voorziet in uitzonderingen. ${ }^{146}$ Daarnaast merkt de Governancecommissie op dat afwijking van een gesloten bepaling niet zonder meer schending van de GCZ oplevert. Afwijking is mogelijk niet onover-

138 GG 20 december 2017 (17/01) (CuraMare), overweging 4.14.

139 GG 20 december 2017 (17/04), GJ 2018/59 (NVZ-ActiZ/Spijkenisse Medisch Centrum), overweging 4.10.

140 GG 3 januari 2017, overweging 4.11 .

141 GG 16 april 2018, overweging 4.23.

142 Zie bijlage 2 bij de Regelgeving verslaggeving WTZi (governance). Zie voor de Wijziging Regeling verslaggeving WTZi verslagjaar 2020, Stcrt. 2019,. 62792, p. 17/18. Deze eis blijft gehandhaafd.

143 Dit gaat wellicht ook op voor de onafhankelijkheid in mindset.

144 GG 17 oktober 2016 (Lievegoed), overweging 3.10.

145 Tenzij de andere zorgorganisatie als groeps- of dochtermaatschappij of anderszins nauw verbonden is met de zorgorganisatie.

146 GG 29 november 2017 (RvT GGZ), overweging 4.3 en GG 30 september 2019, overweging 4.4. 
komelijk als de algemene principes niet werkelijk in het gedrang komen. ${ }^{147}$ In casu was een lid van de RvT benoemd als interim-bestuurder van een andere zorgorganisatie, waarbij beide zorgorganisaties gedeeltelijk dezelfde werkzaamheden verrichtten. ${ }^{148}$ Naar de letter is de bepaling geschonden, maar de Governancecommissie acht deze situatie niet in strijd met de GCZ, omdat er sprake is van een relatieve kleine overlap van werkzaamheden die goed zichtbaar is, ${ }^{149}$ het gaat om een tijdelijke situatie ${ }^{150}$ en er voorzieningen zijn getroffen. ${ }^{151}$

De Governancecommissie maakt ook duidelijk dat de RvT een bevredigende uitleg moet geven waarom geen sprake is van (schijn van) belangenverstrengeling. Dit lijkt mij terecht, dit is een taak van de RvT. Het ligt niet 'op de weg van belanghebbenden om het gevaar van werkelijke belangenverstrengeling aan te tonen of aannemelijk te maken'. ${ }^{152}$ Als een vermoeden rijst bij een derde, moet de RvT kunnen uitleggen waarom hij een situatie wel of niet in strijd met de Code acht.

Samengevat, of sprake is van (de schijn van) belangenverstrengeling hangt sterk af van de omstandigheden van het geval. ${ }^{153}$ Het gaat om concrete voorbeelden. Hieruit blijkt ook dat de situatie(s) van combinaties van functies die (bij voorbaat) door de Code(s) worden afgewezen, slechts een voorbeeld vormen en dat daarmee niet alle combinaties (limitatief) zijn opgesomd, integendeel. ${ }^{154}$

Zoals de IAC al concludeerde dat er meer handvatten gewenst zijn over hoe de GCZ toe te passen, heeft de Governancecommissie hieraan gedeeltelijk voldaan. Het is de vraag of dit voor nu voldoende is voor alle zorgorganisaties. De Governancecommissie geeft weinig

147 GG 29 november 2017 (RvT GGZ), overweging 4.5 en GG 30 september 2019, overweging 4.9. Zie hierover Houwen, Ondernemingsrecht 2020/3, p. 20.

148 De verzorgingsgebieden vallen niet met elkaar samen, maar er is wel sprake van overlap.

149 Het gaat niet om 'echte' concurrenten en de integriteitskwestie is heel concreet, in die zin dat vrijwel direct valt te traceren wanneer de belangen van de beide organisaties zouden kunnen botsen.

150 Als het RvT-lid tijdelijk was teruggetreden zou de schending van de GCZ ook in voldoende mate zijn opgeheven, zie GG 29 november 2017 (RvT GGZ), overweging 4.3.

151 GG 29 november 2017 (RvT GGZ), overweging 4.6. Zie ook GG 30 september 2019 (met name overweging 4.10) over de vraag of de nevenfunctie (lid van een RvT van een andere stichting) van de voorzitter van de RvB strijdig is met de Code. In casu was dat niet het geval.

152 GG 17 oktober 2016 (Lievegoed), overweging 3.7.

153 Het is mogelijk dat een advocaat wordt ingeschakeld die werkt voor een kantoor waartoe een voormalig RvT-lid was toegetreden, zie GG 20 december 2017 (17/01) (CuraMare), overweging 4.16. Volgens de Governancecommissie levert de situatie dat de enig bestuurder van een zorginstelling die tevens (indirect) de houder is van de meerderheid van de aandelen in een andere vennootschap, waarmee wordt gehandeld, de schijn van belangenverstrengeling op, zie GG 26 februari 2019, GJ 2019/89, m.nt. K.D. Meersma \& B. Verkerk, overweging 4.12 (ActiZ/Buurtzorg). Aan de vraag of een medisch specialist lid kan zijn van de RvB van het ziekenhuis, kwam de Governancecommissie niet toe, vanwege de niet-ontvankelijkheid van de verzoeker, zie GG 29 oktober 2018, overweging 4.6.

154 Zie hierover ook GG 17 oktober 2016 (Lievegoed), waarin de vraag aan de orde kwam of er wel of niet terecht een beroep werd gedaan op art. 4.4.4 ZGC. De Governancecommissie had gelijk door te stellen dat een beroep hierop in casu geen hout snijdt, omdat de desbetreffende situatie hier niet onder viel. Dit komt omdat niet alle ongewenste situaties in de Code concreet worden benoemd. Ongewenste situaties kunnen ook voorkomen buiten de kring van bestuurders en leden van de RvT, bijvoorbeeld directeuren. 
algemene richtlijnen. ${ }^{155} \mathrm{Ik}$ vermoed dat de betreffende zorgorganisaties, die verweer moesten voeren bij de Governancecommissie graag eerder handvatten hadden willen hebben.

\subsection{Honorering van leden van de raad van toezicht}

De $\mathrm{RvT}^{156}$ stelt de honorering van de leden van de RvT vast, zo staat in de ZGC en GCZ. ${ }^{157}$ De GCZ voegt daaraan nog toe dat de honorering niet afhankelijk is van de resultaten van de zorgorganisatie en passend is bij de maatschappelijke positie van de zorgorganisatie. Volgens de toelichting bij de ZGC dient de honorering van de leden van de RvT van een zorgorganisatie als maatschappelijke onderneming maatschappelijk passend te zijn en in overeenstemming met de zwaarte van hun complexe taak en verantwoordelijkheden. De adviesregeling van de Nederlandse Vereniging van Toezichthouders in de Zorg (NVTZ) vervult in dit kader een belangrijke rol. ${ }^{158}$ Mocht de RvT die adviezen niet opvolgen of hiervan in belangrijke mate afwijken, dan geeft hij hierover uitleg in de jaarlijkse verantwoording van de zorgorganisatie. ${ }^{159}$

Met een eenvoudige rekensom (een RvT-lid had in 2015 ten hoogste recht op 5\% van de maximumvergoeding van de eigen bestuurder en de voorzitter van de RvT ten hoogste $7,5 \%$ daarvan volgens het jaardocument ${ }^{160}$ ) komt de Governancecommissie tot het oordeel dat de honoreringen niet in overeenstemming zijn met de ZGC. In casu ging het om een bedrag van 7.798 euro boven de norm. ${ }^{161}$ De Governancecommissie toetst, net zoals in de periode 2011-2015, ${ }^{162}$ aan de Code en niet aan de Wet Normering Topinkomens (WNT). ${ }^{163}$

\subsection{Overige onderwerpen}

\subsubsection{Goede Zorg}

Volgens de GCZ staan de behoeftes, wensen, ervaringen en belangen van de cliënt centraal en zijn deze richtinggevend voor de te bieden zorg. ${ }^{164}$ Dit is in de kern gelijk aan hetgeen stond in de ZGC. ${ }^{165}$ In 2017 is in de GCZ daaraan toegevoegd dat de zorg plaatsvindt binnen de gegeven financiële mogelijkheden.

Volgens de Governancecommissie volgt hieruit dat 'de zorgorganisatie tegenover (de vertegenwoordigers van) haar cliënten moet waarmaken dat zij dit principe serieus neemt en

155 De Governancecommissie geeft wel meer uitleg in GG 26 februari 2019, GJ 2019/89, m.nt. K.D. Meersma \& B. Verkerk, overweging 4.12 (ActiZ/Buurtzorg), zie bijvoorbeeld overweging 4.10, 4.15 en 4.20.

156 Of de algemene vergadering, indien aanwezig.

157 Art. 4.3.1 ZGC en bepaling 6.2.5 GCZ.

158 Zie www.nvtz.nl/wat-doen-we/modellen-en-richtlijnen-nvtz. De adviesregeling adviseert 8\% en $12 \%$ (sinds 1 januari 2017).

159 Toelichting bij art. 4.3.1 ZGC.

160 Zie GG 3 januari 2017, overweging 2.8.

161 GG 3 januari 2017, overweging 4.9. De leden van de RvT hebben 27.167 euro ontvangen, terwijl zij recht hadden op 19.369 euro.

162 GG 5 december 2013, GJ 2014/62, overweging 3.11-3.12 (Humanitas). De WNT is wel een richtlijn.

163 De WNT gaat uit van 10\% en 15\%. Dit was 5\% en 7,5\% tot 1 januari 2015.

164 Bepaling 1.1 GCZ.

165 Art. 2.1.1 en 2.1.2 ZGC. 
dat zij over adequate voorzieningen beschikt om te reageren op klachten over het niveau van de zorg ook in individuele gevallen'. ${ }^{166}$

Het is in de ogen van de Governancecommissie de verantwoordelijkheid van de RvB en uiteindelijk ook van de RvT om ervoor zorg te dragen dat klachten (over de zorg(verlening)) op een passend niveau binnen de zorgorganisatie adequaat worden behandeld. Als de bestuurder meent dat de klacht niet door het management of de klachtenfunctionaris kan worden afgehandeld, dient hij zelf adequaat op te treden. Een bestuurder dient de communicatie te zoeken en de toon te vinden waardoor klager zich gehoord voelt. Een klager dient niet van het kastje naar de muur te worden gestuurd, aldus de Governancecommissie. ${ }^{167}$

Volgens Van den Ende kan de Governancecommissie over de band van de GCZ toetsen of de inrichting door de zorginstelling van in feite de verplichtingen die op grond van de Wet kwaliteit, klachten en geschillen zorg (Wkkgz) voor de zorginstelling gelden, voldoende zijn ingericht en ingebed in de organisatie. ${ }^{168}$ De IGJ ziet (ook) toe op de Wkkgz. ${ }^{169} \mathrm{Zij}$ heeft ook mogelijkheden tot handhaving. Volgens de Governancecommissie vormde de rapportage aan de IGJ - de RvB had een onderzoekscommissie ingesteld - geen adequate reactie tegenover de verzoekers. ${ }^{170}$

\subsubsection{Klokkenluidersregeling}

Voor het melden van (vermoedens van) misstanden beschikt de (zorg)organisatie over een klokkenluidersregeling, die openbaar en algemeen vindbaar is, zo staat in de GCZ. ${ }^{171} \mathrm{De}$ vereniging Brancheorganisaties Zorg (BoZ) heeft hiervoor een voorbeeldregeling beschikbaar. ${ }^{172}$ In de ZGC stond al dat de klokkenluidersregeling algemeen bekend wordt gemaakt. $^{173}$

De Governancecommissie volgt de eerdere lijn dat de zorgorganisatie moet aantonen dat zij over een klokkenluidersregeling beschikt en die openbaar maakt. ${ }^{174}$ Een stichting die geen klokkenluidersregeling heeft en ook niet heeft gehandeld overeenkomstig het model voor de klokkenluidersregeling, biedt niet de vereiste bescherming aan zijn werknemers en schendt daarmee de Code. ${ }^{175}$ Dit geldt ook voor een stichting waarbij niet is komen vast te

166 GG 16 april 2018, overweging 4.7. Zie hierover ook par. 2 over de taak van de Governancecommissie.

167 GG 16 april 2018, overweging 4.9. Zie voor de vraag of een beroep op de gegeven financiële mogelijkheden zal slagen overweging 4.11. Overigens is de Code niet geschonden, zie overweging 4.12.

168 Van den Ende, TvGR 2018, p. 313.

169 De afhandeling van individuele klachten valt niet onder de verantwoordelijkheid van de IGJ. De klacht van de familie was door het Landelijk Meldpunt Zorg (onderdeel van IGJ) doorgezonden aan de IGJ (overweging 4.8). Bij veel of ernstige signalen over een zorgaanbieder kan de IGJ besluiten een onderzoek te doen. De IGJ lost de klacht niet op. Op basis van het onderzoek kan de IGJ wel maatregelen treffen tegen de zorgaanbieder. Zie www.igj.nl/onderwerpen/klacht-of-vraag-over-zorg-of-jeugdhulpverlening/ik-heb-een-klacht/ klacht-zorgaanbieder/klacht-melden-bij-inspectie.

170 GG 16 april 2018, overweging 4.8 en 4.9 .

171 Bepaling 2.5.2 GCZ.

172 Zie voor de Modelregeling 2018 www.brancheorganisatieszorg.nl/category/governance.

173 Art. 3.1.5 ZGC.

174 GG 24 november 2015, GJ 2016/63, m.nt. A.F.H. ten Brummelhuis (GGZ Nederland/GGZ Noord-HollandNoord), overweging 4.7 en 4.8 .

175 GG 3 januari 2017, overweging 4.8 . 
staan dat zij tijdig en adequaat heeft voldaan aan het algemeen bekendmaken of vindbaar zijn van een klokkenluidersregeling. ${ }^{176}$

Het belang van een klokkenluidersregeling moet niet onderschat worden. Een goed functionerende klokkenluidersregeling kan veel ellende, zoals negatieve media-aandacht, voorkomen, aldus Keijzer. ${ }^{177}$

\section{Conclusie}

De Governancecommissie volgt de eerder uitgezette lijnen in de uitspraken uit 2011-2015. Het begrip belanghebbende dient (nog steeds) ruim te worden genomen, maar is niettemin begrensd, zo is inmiddels gebleken. Wellicht is de invulling die de Governancecommissie aan het begrip geeft niet geheel conform het Reglement, maar de rol van de Governancecommissie komt (nog steeds) wel tot haar recht. ${ }^{178}$ Daarnaast geeft de Governancecommissie meer duidelijkheid over een aantal eisen in het Reglement over de ontvankelijkheid van het toetsingsverzoek, zoals wanneer is een verzoek schriftelijk kenbaar gemaakt en wanneer is sprake van constructief overleg. De lat ligt hierbij niet al te hoog. Bij de invulling van de eisen, (vanaf) wanneer de termijn van twaalf maanden gaat lopen en wanneer sprake is van een concreet omschreven geval, kiest de Governancecommissie voor een meer praktische insteek.

De taak van de RvT wordt door de Governancecommissie nader uitgewerkt, in het bijzonder het functioneren van de RvT ten opzichte van de RvB. Volgens de Governancecommissie dient de RvT voldoende afstand te bewaren tot de RvB. Uit de uitspraken volgt ook dat (zelf)evaluaties van de RvT (en met de RvB) niet onderschat dienen te worden. Verder blijkt uit de uitspraken dat collectief aftreden van de RvT niet past niet bij zijn taak als toezichthouder en werkgever. Bovendien dient een lid van de RvT (in het kader van de werkgeversrol) volledige zeggenschap te hebben over de selectie- en benoemingsprocedure van een bestuurder en heeft het RvT-lid recht op bepaalde informatie, zoals de tekst van de arbeidsovereenkomst met de bestuurder. Voor de werving van een RvT-lid geldt dat in de openbare procedure namen door (een lid van) de RvT en RvB mogen worden genoemd.

Bovendien geeft de Governancecommissie meer helderheid over de vereiste onafhankelijkheid van de leden van de RvT. In deze uitspraken lijkt het te gaan om onafhankelijkheid in mind(set). Een RvT dient onafhankelijk van een deelbelang te (kunnen) functioneren. Daarnaast geeft de Governancecommissie (beperkt) duidelijkheid over wanneer wel of niet sprake is van (de schijn van) belangenverstrengeling. Dit is sterk afhankelijk van de omstandigheden van het geval, zo blijkt uit de uitspraken. Het gaat om concrete gevallen en het accent lijkt te liggen op onafhankelijkheid in appearance, oftewel: welke indruk kunnen derden hebben van de situatie? Helaas geeft de Governancecommissie op dit punt weinig algemene richtlijnen. De vraag is of dit voldoende is voor de praktijk.

176 GG 16 april 2018, overweging 4.18 en 4.19. In casu was ook geen rechtvaardiging aangevoerd.

177 F. Keijzer, 'De klokkenluidersregeling: een must have voor de zorgaanbieder', 16 april 2018, zie www.dirkzwager.nl/kennis/artikelen/de-klokkenluidersregeling-een-must-have-voor-de-zorgaanbieder.

178 Zie ook Klaassen, TvGR 2016, p. 188. 
Met deze uitspraken verschaft de Governancecommissie in elk geval (meer) duidelijkheid hoe een aantal codebepalingen (en bepalingen uit het Reglement) in de praktijk nader ingevuld moeten worden. In sommige uitspraken geeft de Governancecommissie zelfs een aantal nuttige adviezen. In de uitspraken van 2011-2015 stond de dans rond de stoel van de bestuurder centraal, in de periode 2016-2019 stond de RvT in de schijnwerpers. 